\title{
APLIKASI PENGEKSTRAK CIRI KERIPUT WAJAH MANUSIA DENGAN PENDEKATAN KEACAKKAN STATISTIS ENTROPI
}

\author{
Syukri Gazali Suatkab ${ }^{1}$, Alphin Stephanus (Stevie) $)^{2}$ \\ 1,2Jurusan Teknik Elektro, Politeknik Negeri Ambon \\ Email: ${ }^{1}$ syukrisuatkab@gmail.com, ${ }^{2}$ peppymusila52@gmail.com
}

(Naskah masuk: 24 Juni 2021, diterima untuk diterbitkan: 30 Juni 2021)

\begin{abstract}
Abstrak
Proses penuaan merupakan hal yang tidak bisa dihindari dan sifatnya alami pada manusia. Perubahan wajah manusia terjadi secara signifikan seiring dengan bertambahnya usia. Aspek-aspek yang mempengaruhi perubahan ini antara lain: heriditas, psikologis, nutrisi, lifestyle, ras maupun dearah geografis. Manusia memiliki kebutuhan yang berbeda pada setiap kelompok usia. Sebagai konsekuensi perkembangan ilmu pengetahuan, teknologi dan informasi maka dibutuhkan layanan publik yang dapat membantu manusia dalam memenuhi kebutuhan berdasarkan kelompok umur. Untuk dapat mengelompokkan umur dengan baik maka dibutuhkan diskriptor yang baik sebagai ciri pembeda utama. Penelitian ini menggunakan MATLAB 7.8 berbasis GUI (Graphic User Interface) untuk membuat aplikasi pengekstrak ciri keriput wajah. Pengekstrakan ciri citra dibagi menjadi dua sub proses yaitu pra pengolahan citra dan ekstraksi ciri. Praproses diawali dengan Cropping citra asli menjadi lebih kecil, pengubahan citra warna menjadi citra aras keabuan (grayscale), melakukan histogram equalization dan cropping pada 5 daerah kerutan wajah. Berdasarkan lima daerah kerutan wajah manusia tersebut, dihasilkan ciri tekstur sebagai ciri keriput diperoleh dari pendekatan keacakan statistis yaitu entropi. Penelitian ini menggunakan 12 citra wajah laki-laki dengan batasan umur 20 tahun sampai dengan diatas 60 tahun sebagai bahan sampel. Sistem ini berhasil mengekstrak seluruh sampel citra wajah. Dan akhirnya aplikasi ini diharapkan dapat menjadi referensi yang dapat diimplementasikan dibidang yang lain.
\end{abstract}

Kata kunci: pengolahan citra, ekstrak ciri, cropping, histogram equalization, entropi.

\section{HUMAN FACE WRINKLES EXTRACTOR APPLICATION WITH ENTROPY STATISTIC RANDOM APPROACH}

\begin{abstract}
Aging process are natural and can not be avoided especially for human being. Human face changes significantly with the advancing age. Aspects that effecting this changes are heredity, psychologies, nutrient, lifestyle, race and geographies. People's behavior and preference are different at different ages. As consequence of the growing science, technology and information, a public service be needed to support human needs based on age classification. To yield a good classifier, a good descriptor was needed as a feature distinction. MATLAB 7.8 based on GUI was being used to develop the application. The process is divided into two sub process i.e. image pre processing and feature extraction. Image Cropping was a first step from all process to resizing image to become smaller, changed color image to grayscale image, histogram equalization and the last step was cropping gray image into 5 region of wrinkle potentially from human face. Based on five regions of human face, the respective five wrinkle features from each facial image were obtained through a statistical of randomness (entropy) approach. The sample of this research was 12 male images face from 20 to 60 years of age and was succeed extracted all sample. This application hopefully can be implemented in other fields of study.
\end{abstract}

Keywords: image processing, feature extract, cropping, histogram equalization, entropi.

\section{PENDAHULUAN}

Ketika seseorang bertambah tua terjadi perubahan yang signifikan terhadap wajahnya. Penuaan merupakan proses yang tidak bisa dihindari. Proses alamiah penuaan mempengaruhi wajah manusia dalam berbagai variasi. Aspek-aspek yang mempengaruhi perubahan ini antara lain; heriditas, psikologi,nutrisi, lifestyle, ras dan daerah 
geografis (Richa, 2007; Gandhi, 2004; Petterson, 2002). Menurut data pada Roswell Park Cancer Institute, seseorang yang merokok satu pak perhari sebagai gaya hidup akan menjadi keriput dan menjadi lebih tua 1,4 kali. Jadi seorang perokok berumur 30 tahun tampak seperti berumur 42 tahun (Gandhi, 2004).

Menurut Xin Geng et al (2007), manusia yang berbeda umur berbeda pula kebutuhan dan pilihannya dalam banyak aspek seperti berbahasa, estetika dan kebiasaan konsumsi. Maka sebagai konsekuensi logis, lingkungan yang berbasis teknologi komputer seperti Age Spesific Human Computer Interaction (ASHCI) dibutuhkan secara luas untuk banyak aplikasi sehari-hari. Contoh pemanfaatan aplikasi ASHCI antara lain :

1. Terminal enquiry dapat secara otomatis memilih kosakata, interface dan pelayanan yang cocok sesuai umur pelanggan;

2. Web browser yang dapat menampilkan halaman-halaman web berdasarkan batasan umur; atau menolak untuk menjual minuman beralkohol atau rokok pada anak dibawah umur (Draper, 2003; Geng, 2007).

Contoh lain dalam kaitannya dengan peningkatan aplikasi layanan publik, pemerintah Indonesiapun berusaha meningkatkan diri dengan visi, "Terwujudnya masyarakat informasi yang sejahtera melalui penyelenggaraan komunikasi dan informatika yang efektif dan efisien dalam kerangka Negara Kesatuan Republik Indonesia" serta memiliki misi antara lain: 1. Meningkatkan kapasitas layanan informasi dan pemberdayaan potensi masyarakat dalam rangka mewujudkan masyarakat berbudaya informasi, 2. Mendorong peningkatan aplikasi layanan publik dan industri aplikasi telematika dalam rangka meningkatkan nilai tambah layanan dan industri aplikasi (Depkominfo, 2020).

Jadi pengelompokan berdasarkan umur itu penting dan sudah lazim dilakukan dalam kehidupan sehari-hari. Hal ini juga merupakan salah satu usaha untuk menjawab kebutuhan manusia dalam berbagai aplikasi layanan publik dengan memanfaatkannya sebagai dasar menyeleksi, membatasi atau mengukur.

\section{TINJAUAN PUSTAKA}

Manusia memiliki kemampuan yang luar biasa dalam mengenali suatu obyek, bahkan ketika obyek tersebut mengalami perubahan. Wajah merupakan salah satu obyek pengenal dalam interaksi sosial manusia. Perubahan visual wajah yang terjadi akibat kondisi penglihatan, ekspresi, umur dan penghalang lain seperti kacamata atau yang lainnya tidak menurunkan kehandalan kemampuan manusia dalam mengenali wajah seseorang, bahkan manusia dapat membedakan dua orang kembar identik. Dalam suatu penyelidikan (Geng, 2007) menunjukkan bahwa hanya 7 persen maksud lewat kata yang dapat diterjemahkan dalam perintah komputer, sisanya 93 persen diekspresikan lewat wajah. Dari sebuah citra wajah dapat dengan mudah diekstrak banyak informasi yang berguna seperti identitas, ekspresi, emosi, gender, umur dan lain-lain. Dalam Implementasinya Interaksi Manusia-Komputer (Human Computer Interaction-HCI) berbasis citra wajah saat ini sedang ditingkatkan untuk menjadi pengenal dan penginterpretasi pada sistem contactless.

Keriput pada wajah merupakan ciri penuan manusia dan merupakan hal yang alamiah dan wajar. Bagi manusia sangat mudah mengenali kriput pada wajah yang dilihatnya. Namun bagi komputer dalam suatu sistem pengolahan citra hal ini sama sekali tidak mudah. Dalam penelitian ini digunakan tekstur analisis dengan pendekatan ukuran keacakan statistik yaitu entropi sebagai pengekstrak ciri keriput pada wajah manusia.

\subsection{Data Citra}

Citra sebagai data pada sistem visi mesin adalah fungsi kontinyu dari intensitas cahaya pada bidang dua dimensi $f(x, y)$ dengan $x$ dan $y$ adalah koordinat spasial dan $\mathrm{f}$ pada koordinat $(\mathrm{x}, \mathrm{y})$ yang merupakan tingkat kecerahan (brightness) suatu citra di suatu titik.

Untuk mengubah citra kontinyu menjadi digital diperlukan proses pembuatan kisi-kisi arah horizontal dan vertikal sehingga diperoleh gambar dalam bentuk larik dua dimensi dan proses ini dikenal sebagai proses digitalisasi atau sampling. Citra digital yang mempunyai tinggi $\mathrm{N}$ dan lebar $M$ serta derajat keabuan $L$ dapat dianggap sebagai fungsi yang dinyatakan pada Persamaan 1.

$$
f(x, y)=\left\{\begin{array}{l}
0 \leq x \leq M \\
0 \leq x \leq N \\
0 \leq f \leq L
\end{array}\right.
$$

Citra digital yang berukuran $N \times \quad M$ lazim dinyatakan dengan matriks nilai intensitas citra pada koordinat masing-masing yang berukuran $\mathrm{N}$ baris dan M kolom dengan elemen-elemen berupa sebaran angka dan dinyatakan pada Persamaan 2.

$$
\begin{aligned}
& f(x, y) \\
& =\left|\begin{array}{cclc}
f(0,0) & f(0,1) & \cdots & f(0, M) \\
f(1,1) & f(1,1) & \cdots & f(1, M) \\
\vdots & \vdots & & \vdots \\
f(N-1,0) & f(N-1,1) & \cdots & f(N-1, M-1)
\end{array}\right|
\end{aligned}
$$

\subsection{Pra Pengolahan Citra}

Pra pengolahan citra adalah transformasi input data mentah untuk membantu kemampuan 
komputasional dan pencari ciri serta untuk mengurangi derau (Putra, 2008). Proses awal dalam penelitian ini antara lain, pemotongan bagian citra (cropping), mengubah citra berwarna menjadi citra grayscale, meningkatkan kualitas citra (image enhancement) dengan menggunakan ekualisasi histogram (histogram equalization), serta melakukan pengekstrakcirian (feature extraction). Hal ini dilakukan untuk menghasilkan ekstrak ciri yang baik.

\subsubsection{Cropping}

Cropping adalah usaha untuk memotong satu bagian dari citra sehingga diperoleh citra dengan ukuran lebih kecil yang dapat diproses tanpa kehilangan esensi informasinya. Operasi ini pada dasarnya adalah operasi translasi yaitu menggeser koordinat titik citra, dengan mengurangi jumlah pixelnya. Persamaan matematis yang digunakan untuk operasi cropping dinyatakan pada Persamaan 3 dan 4.

$$
\begin{gathered}
x^{\prime}=x-x_{L} \text { untuk } x=x_{L} \text { hingga } x_{R} \\
y^{\prime}=y-y_{T} \text { untuk } y=y_{T} \text { hingga } y_{B}
\end{gathered}
$$

$\left(\mathrm{x}_{\mathrm{L}}, \mathrm{y}_{\mathrm{T}}\right)$ dan $\left(\mathrm{x}_{\mathrm{R}}, \mathrm{y}_{\mathrm{B}}\right)$ masing-masing adalah koordinat titik pojok kiri atas dan pojok kanan bawah bagian citra yang di-crop [1]. Gambar 1 menunjukkan ilustrasi dari koordinat titik pojok kiri atas dan pojok kanan bawah citra yang di-crop. Sehingga ukuran citra hasil crop dinyatakan dalam Persamaan 5 dan 6.

$$
\begin{gathered}
w^{\prime}=x_{R}-x_{L} \\
h^{\prime}=y_{B}-y_{T}
\end{gathered}
$$

dan transformasi baliknya dinyatakan pada Persamaan 7 dan 8 .

$$
\begin{aligned}
& x=x^{\prime}-x_{L} \text { untuk } x^{\prime}=0 \text { hingga } w^{\prime}-1 \\
& y=y^{\prime}+y_{T} \text { untuk } y^{\prime}=0 \text { hingga } h^{\prime}-1
\end{aligned}
$$

\subsubsection{Mengubah citra berwarna menjadi citra grayscale}

Proses prapengolahan citra yang banyak dilakukan adalah mengubah citra warna (true color) menjadi citra keabuan (grayscale). Hal ini digunakan untuk menyederhanakan model citra. Perhitungan yang diterapkan pada citra warna dilakukan menggunakan tiga lapis (layer) yaitu Rlayer, G-layer dan B-layer. Apabila menginginkan perhitungan yang sederhana maka citra warna dapat dikonversi menjadi citra keabuan yaitu mengubah 3 layer matriks citra warna menjadi 1 layer matriks citra keabuan (Achmad \&Kartika, 2005). Dalam proses mengubah citra berwarna menjadi citra grayscale, tiga layer RGB diubah menjadi 1 layer matriks grayscale. Dalam citra ini tidak ada lagi warna, yang ada adalah derajat keabuan.

Menurut Achmad (Achmad \&Kartika, 2005) citra warna dapat dikonversikan menjadi citra keabuan dengan operasi titik. Dalam definisi ringkasnya intensitas adalah nilai rerata dari ketiga elemen warna sehingga nilai keabuan yang merepresntasikan intensitas dapat dihitung dengan Persamaan 9.

$$
K_{o}=\frac{R_{i}+G_{i}+B_{i}}{3}
$$

Ko sebagai nilai rerata dari ketiga komponen warna RGB yang diubah menjadi citra keabuan bukanlah suatu keharusan. Meskipun hasilnya cukup baik, penggunaan nilai rerata masih belum optimal untuk menunjukkan citra keabuan sehingga terkadang harus dilakukan pengubahan komposisi warna, sehingga Persamaan (9) dimodifikasi menjadi Persamaan 10.

$$
K_{o}=\omega_{R} R_{i}+\omega_{G} G_{i}+\omega_{B} B_{i}
$$

Dengan $\square \mathrm{R}, \square \mathrm{G}, \square \mathrm{B}$ masing-masing adalah bobot untuk elemen warna merah, hijau dan biru. NTSC (National Television System Committee) mendefinisikan bobot untuk konversi citra ke warna keabuan sebagai berikut:

$$
\omega_{R}=0.299 ; \omega_{G}=0.587, \omega_{B}=0.114
$$

Sehingga persamaan (10) jika disubtitusikan dengan nilai bobot pada persamaan (11) dapat ditulis kembali menjadi Persamaan 12.

$$
K_{o}=0.299 R_{i}+0.587 G_{i}+0.114 B_{i}
$$

\subsubsection{Image enhancement dengan histogram equalization}

Pengubahan histogram derajat keabuan merupakan salah satu dari operasi dalam pengolahan citra yang bertujuan untuk meningkatkan kualitas citra. Informasi penting mengenai isi citra digital 
dapat diketahui dengan membuat histogram citra. Menurut Munir (2003) histogram citra adalah grafik yang menggambarkan penyebaran jumlah piksel berdasarkan nilai-nilai intensitas suatu citra atau bagian tertentu atas citra. Secara matematis histogram citra dihitung dengan Persamaan 13 (Gonzales \& Woods, 2008).

$$
p_{r}\left(r_{k}\right)=\frac{n_{k}}{M N}, k=0,1, \cdots, L-1
$$

dengan $\operatorname{pr}(\mathrm{rk})=$ probabilitas terjadinya derajat intensitas rk. nk adalah jumlah piksel yang memiliki intensitas rk dan $\mathrm{MN}$ adalah jumlah total piksel pada citra.

Sering kali terjadi perbedaan intensitas pada objek rekam yang sama dalam suatu citra secara visual. Hal ini disebabkan karena perbedaan intensitas cahaya pada lingkungan objek. Perbedaan intensitas dapat diketahui dengan cara memberikan kontras yang signifikan pada citra asli dengan cara ekualisasi histogram (Gonzales \& Woods, 2008). Secara matematis ekualisasi histogram citra dihitung dengan Persamaan 14.

$$
T\left(r_{k}\right)=(L-1) \sum_{j=0}^{k} p_{r}\left(r_{j}\right)
$$

\subsection{Ekstraksi Ciri (Feature Extraction)}

Kunci dalam setiap sistem klasifikasi adalah bagaimana menemukan suatu set ciri yang handal sebagai basis kategorisasi (Putra, 2008). Pada penelitian ini dilakukan ekstraksi ciri tekstur yang didapat dari histogram citra. Ekstraksi ciri bertujuan untuk mendapatkan ciri-ciri dari suatu objek. Ciriciri tersebut akan digunakan untuk mengenali suatu objek sesuai dengan kategorinya. Ciri-ciri yang dapat diekstrak dari citra antara lain adalah ciri spasial (spatial features), ciri histogram (histogram features), ciri alih ragam (transform features), ciri bentuk (shape features) dan ciri tekstur (texture features). Ciri-ciri histogram (histogram features) diperoleh berdasarkan histogram citra. Misalkan u adalah variabel acak yang menyatakan aras keabuan pada citra maka dapat didefinisikan dalam Persamaan 15.

$$
\begin{gathered}
p_{u}(x) \triangleq \operatorname{prob}[u=x]= \\
\frac{\text { jumlah piksel dengan aras keabuan } x}{\text { jumlah total piksel dalam citra }}
\end{gathered}
$$

Dengan nilai x dari 0 hingga L-1, dan L adalah jumlah aras keabuan dalam citra (256 untuk citra dengan aras keabuan yang dinyatakan dalam delapan bit). Ciri-ciri umum dari pu(x) diantaranya adalah momen dan entropi, dinyatakan dalam Persamaan 16-20.

$$
\text { Moments, } \quad m_{i}=E\left[u^{i}\right]=\sum_{x=0}^{L-1} x^{i} p_{u}(x)
$$

Abselute moments, $\quad \widehat{m}_{l}=E\left[|u|^{i}\right]=\sum_{x=0}^{L-1}|x|^{i} p_{u}(x)$
Central moment, $\mu_{i}=E\left\{[u-E(u)]^{i}\right\}=\sum_{x=0}^{L-1} x^{i} p_{u}(x)$

Abselute central moment,

$$
\widehat{\mu_{\iota}}=E\left[|u-E(u)|^{i}\right]=\sum_{x=0}^{L-1}\left|x-m_{1}\right|^{i} p_{u}(x)
$$

Entropi,

$$
H=E\left[-\log _{2} p_{u}\right]=-\sum_{x=0}^{L-1} p_{u}(x) \log _{2} p_{u}(x) \text { bit }
$$$$
\text { dengan } i=1,2,3, \ldots
$$

Entropi merupakan ukuran keacakan (randomness) statistik yang dapat digunakan untuk mengetahui karakter tekstur citra input (Gonzales \& Woods, 2008). Entropi adalah rerata yang dibangkitkan oleh sumber informasi. Sumber informasi adalah sebuah sistem yang menghasilkan keluaran dari satu set simbol (misalnya M simbol) dalam bentuk urutan (sequence). Citra digital merupakan sumber informasi berupa piksel-piksel independen dan entropi dapat diestimasi dari histogramnya. Berdasarkan kekhasan ini maka digunakan Entropi untuk mengekstrak ciri tekstur wajah dalam penelitian ini.

Berikut diberikan ilustrasi dengan sebuah matriks yang menggambarkan sebuah citra aras keabuan. Misalnya matriks pada Gambar 2 diperoleh dari pembacaan nilai piksel citra yang berukuran $5 \times 5$, maka setiap elemen pada matriks tersebut adalah sebuah simbol dan jumlah total simbol yang ada adalah 25 .

\begin{tabular}{|lllll|}
\hline 10 & 10 & 70 & 65 & 10 \\
15 & 70 & 75 & 100 & 100 \\
15 & 70 & 100 & 100 & 100 \\
10 & 15 & 100 & 70 & 65 \\
15 & 15 & 10 & 70 & 10 \\
\hline
\end{tabular}

Gambar 2 Contoh matriks 5x5

Dari matriks tersebut diketahui bahwa untuk masing-masing simbol $\left[\begin{array}{llllll}10 & 15 & 65 & 70 & 75 & 100\end{array}\right]$ mempunyai peluang kemunculan sebesar [0.24 0.20 $\left.\begin{array}{llll}0.28 & 0.20 & 0.04 & 0.24\end{array}\right]$. Dengan menggunakan persamaan (20) maka untuk citra tersebut dapat ditentukan entropinya sebesar:

Entropi $=-\left(0.24 \log _{2} 0.24+0.2 \log _{2} 0.2+0.08 \log _{2}\right.$ $0.08+0.04 \log _{2} 0.04+0.24 \log _{2} 0.24$ )

$$
=2.208 \mathrm{bit} / \mathrm{piksel}
$$

Menurut Horng (2001), keriput pada wajah lebih Nampak jelas seiring dengan bertambahnya usia. Orang yang sudah berumur seringkali keriputnya nampak jelas pada wilayah wajah sebagai berikut:

- Dahi memiliki kerut horizontal

- Keriput pada sudut mata 
- Terdapat cekungan dan garis yang dalam pada daerah pipi bagian atas bibir.

Untuk memahami lebih jelasnya, maka wilayah keriput yang akan dicari cirinya dapat dilihat pada Gambar 3.

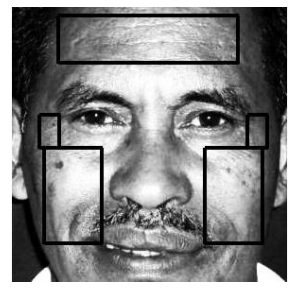

Gambar 3. Lima wilayah keriput untuk ekstraksi ciri

\section{METODE PENELITIAN}

Pengekstrakan ciri citra dibagi menjadi dua sub proses yaitu pra pengolahan citra dan ekstraksi ciri. Praproses diawali dengan Cropping citra asli menjadi lebih kecil, pengubahan citra warna menjadi citra aras keabuan (grayscale), melakukan histogram equalization dan cropping (5 daerah kerutan wajah). Proses ini diakhiri dengan ekstraksi ciri dengan menggunakan ukuran keacakan (randomness) statistik yaitu entropi. Bahan atau materi sebagai sampel yang digunakan pada penelitian ini adalah berupa citra wajah manusia laki-laki dengan batasan umur 20 tahun sampai dengan diatas 60 tahun berjumlah 12 sampel.

Peralatan yang digunakan di dalam penelitian ini berupa perangkat lunak dan perangkat keras sebagai berikut:

1) Perangkat Lunak: MATLAB 7.8 - R2016a, Ms.

Office 2007 dan Adobe Photoshop 7.0.

2) Untuk mendukung perangkat lunak diatas maka spesifikasi normal perangkat kerasnya adalah seperti pada penelitian ini yaitu : 1 Unit Laptop merek ACER Aspire type 4315, INTEL Celeron $1,86 \mathrm{GHz}, \mathrm{RAM} 512 \mathrm{MB}$ DDR2, HDD $80 \mathrm{~GB}$, monitor LCD 14,1"WXGA dengan system Operasi Windows XP,

3) Kamera digital Sony W110, Resolusi 7,2 Mega Pixel, Lensa Carl Zeiss,

Blok diagram penelitian ditunjukkan pada Gambar 4 dan terbagi atas 5 proses yaitu:

1. Pengambilan sampel

2. Perekaman citra

3. Pra PengolahanCitra

4. Proses Ekstraksi Ciri

5. Hasil

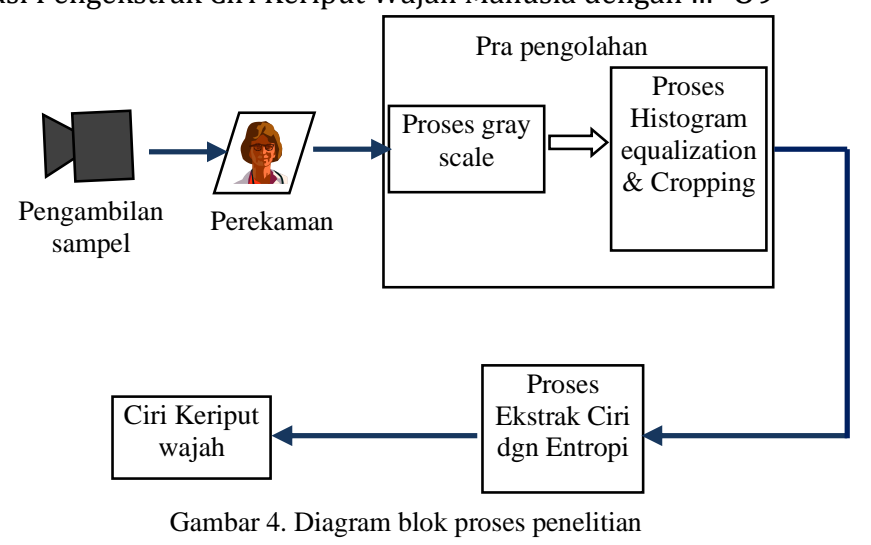

\section{HASIL DAN PEMBAHASAN}

\subsection{Pengambilan Sampel}

Pengambilan sampel dilakukan pada wajah laki-laki usia 20 sampai dengan diatas 60 tahun. Hal ini dilakukan karena belum adanya sistem prediksi kategori umur yang terspesifik orang Indonesia yang beragam.

\subsection{Perekaman Citra}

Citra sampel wajah direkam dengan resolusi 640x480 piksel dengan format penyimpanan berekstensi .jpg. Resolusi yang dipilih dianggap sudah mencukupi kriteria yang dibutuhkan untuk objek wajah manusia. Setiap orang direkam sebanyak satu kali sehingga citra sampel yang dihasilkan adalah 64 buah. Pengambilan citra ini dilakukan dengan menempatkan seseorang dengan suatu latar belakang dan jarak tertentu. Latar belakang ini adalah kain berwarna gelap sehingga mengurangi pantulan cahaya dan memberikan perbedaan warna terhadap objek. Gambar 5. adalah contoh citra sampel dengan resolusi 640 x 480 .

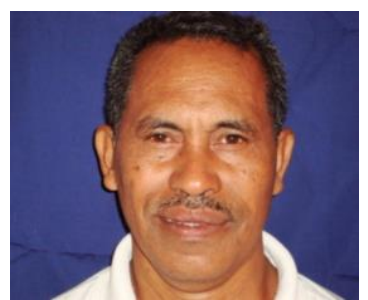

Gambar 5. Citra Sampel dengan Resolusi 640 x 480

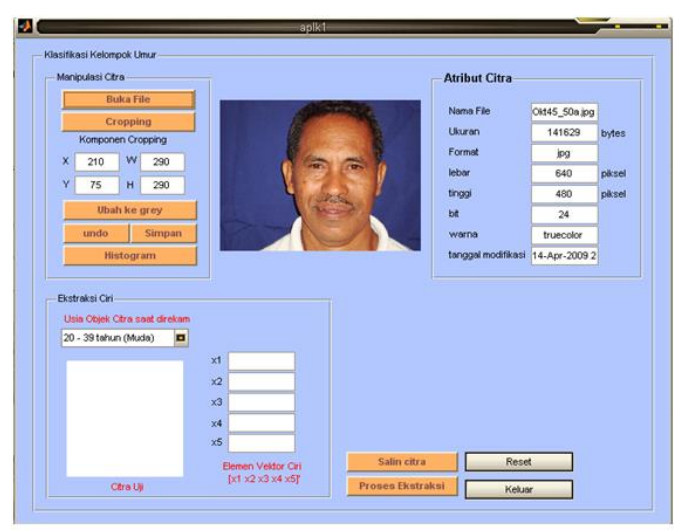

Gambar 6. Antar muka aplikasi pengekstrak ciri 


\subsection{Pra Pengolahan Citra}

Pra pengolahan citra pada penelitian ini seperti pada bab sebelumnya terdiri atas beberapa tahapan antara lain:

a. Cropping

b. Pengubahan citra warna menjadi citra aras keabuan

c. Peningkatan kualitas citra dengan Histogram Equalisasi

Proses Prapengolahan citra ini sudah menggunakan aplikasi sistem yang sudah dikembangkan. Antar muka aplikasi pada penelitian ini ditampilkan pada Gambar 6.

\subsubsection{Cropping}

Pada penelitian ini prapengolahan yang dilakukan adalah memperkecil ukuran citra dengan proses cropping. Bagian yang tidak diperlukan dalam proses klasifikasi dapat dihilangkan.Ukuran citra yang digunakan dalam penelitian ini adalah 291 x 291 karena mewakili batasan wajah target keriput. Hasil cropping citra sampel resolusi 640 x 480 menjadi 291 x 291.

Contoh sintaks Matlab untuk proses cropping adalah sebagai berikut :

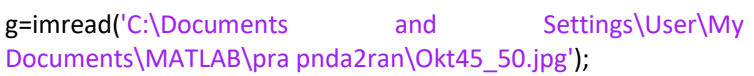

$A=[22075290$ 290];\% lokalisir wilayah cropping

$\mathrm{C}=\mathrm{imcrop}(\mathrm{g},[\mathrm{A}]) ; \%$ perintah cropping pada toolbox matlab figure,imshow(C); \% perintah menampilkan citra pada toolbox matlab

Perbandingan ukuran citra sebelum dan sesudah proses cropping dicontohkan pada Tabel 1 .

\begin{tabular}{|l|l|l|l|l|l|l|}
\hline \multicolumn{2}{|l}{ Tabel 1. Ukuran Citra sebelum dan sesudah proses cropping } \\
\hline & \multicolumn{2}{|l|}{ Ukuran Relatif } & \multicolumn{2}{l|}{ Ukuran Citra Aktual } & \multicolumn{2}{l|}{$\begin{array}{l}\text { Dimensionalitas } \\
\text { (Jumlah Piksel) }\end{array}$} \\
\cline { 2 - 7 } & Sebelum & Sesudah & Sebelum & Sesudah & Sebelum & Sesudah \\
\hline Okt45_50 & $142 \mathrm{~KB}$ & $15 \mathrm{~KB}$ & $480 \times 640$ & $291 \times 291$ & 307200 & 84681 \\
& & & & & & \\
\hline
\end{tabular}

Tahap kedua dari proses prapengolahan pada penelitian ini adalah pengubahan citra warna menjadi citra aras keabuan (grayscle). Alasan mengenai penggunaan citra aras keabuan pada penelitian ini seperti yang sudah dipaparkan pada bab dua dan bab tiga yaitu untuk menyederhanakan model citra dan meringankan beban komputasi.

Contoh sintaks yang digunakan untuk mengubah citra warna ke citra graycale adalah sebagai berikut:

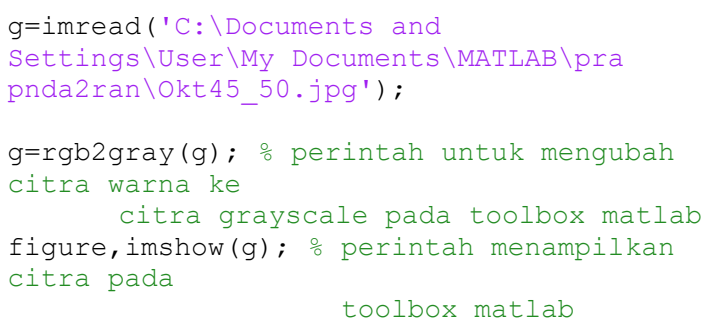

Perbandingan ukuran citra relatif sebelum dan sesudah proses pengubahan citra ke grayscale dicontohkan pada Tabel 2.

Tabel 2 Ukuran Citra setelah proses greyscaling

\begin{tabular}{|c|c|c|c|l|c|c|}
\hline \multirow{2}{*}{ Nama File } & \multicolumn{2}{|c|}{ Ukuran Relatif } & \multicolumn{2}{c|}{ Ukuran Citra Aktual } & \multicolumn{2}{c|}{$\begin{array}{c}\text { Dimensionalitas (Jumlah } \\
\text { Piksel) }\end{array}$} \\
\cline { 2 - 7 } & Sebelum & Sesudah & Sebelum & Sesudah & Sebelum & Sesudah \\
\hline Okt45_50 & $15 \mathrm{~KB}$ & $13 \mathrm{~KB}$ & $291 \times 291$ & $291 \times 291$ & 84681 & 84681 \\
\hline
\end{tabular}

\subsubsection{Peningkatan kualitas citra dengan \\ dan 9 adalah gambar histogram citra sampel sebelum} histogram equalization

Proses akhir dalam tahap pra pengolahan adalah peningkatan kualitas citra dengan ekualisasi histogram. Proses ini dilakukan untuk mengurangi efek pencahayaan yang bervariasi dan sulit untuk dihindari. Hasil proses ekualisasi histogram dapat dilihat secara berurut yaitu Gambar 7 adalah hasil ekualisasi histogram pada citra sampel, Gambar 8

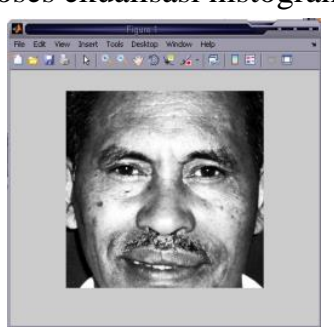

Gambar 7. Hasil Ekualisasi histogram 


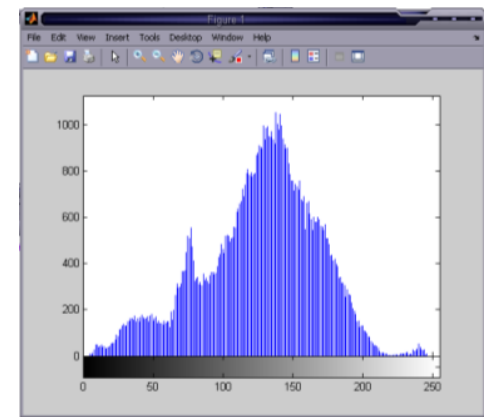

Gambar 8. Histogram Citra Sebelum Prose

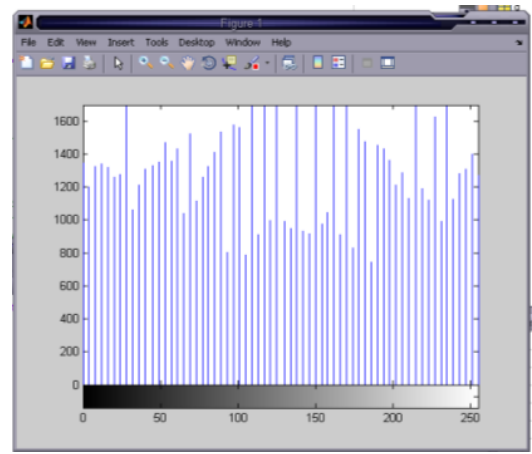

Gambar 9. Histogram Setelah proses ekualisasi histogram

\subsection{Proses Ekstraksi Ciri}

Ekstrak ciri bertujuan untuk mengenali suatu diskriptor yang menggambarkan karakteristik dari objek. Pada penelitian ini digunakan ukuran keacakan statistik, entropi untuk menggambarkan karakteristik tekstur pada wajah manusia. Hasil dari ekstraksi ciri dibentuk menjadi suatu vektor yang disebut sebagai vektor ciri yang nantinya dijadikan masukan pada sistem klasifikasi penelitian ini. Gambar 10 menjadi contoh yang memperlihatkan hasil ekstraksi ciri dari suatu citra uji.

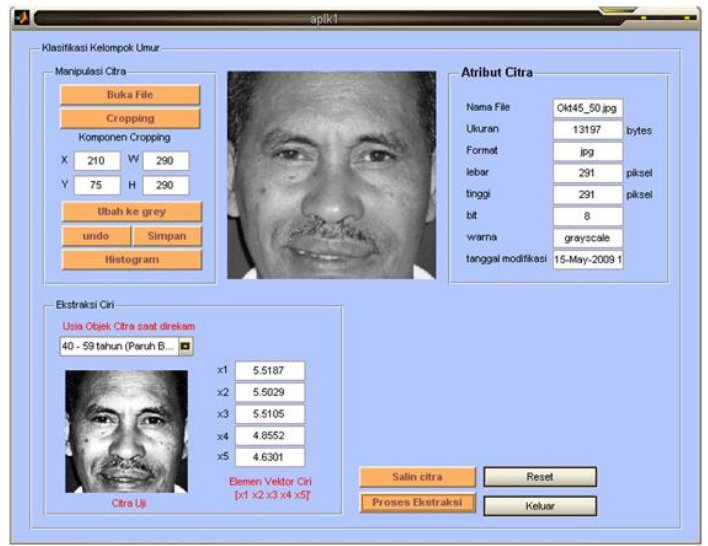

Gambar 10. Hasil Ekstrasi Ciri

Hasil rekapitulasi ekstraksi ciri seluruh citra data di masukkan dalam suatu tabel seperti yang ditunjukkan Tabel 3.

\begin{tabular}{|c|c|c|c|c|c|c|c|c|c|c|c|c|}
\hline & Cit1 & Cit2 & Cit3 & Cit4 & Cit5 & Cit6 & Cit7 & Cit8 & Cit9 & Cit10 & Cit11 & Cit12 \\
\hline da(x1) & 5.44159 & 5.404 & 5.6043 & 5.43623 & 5.52536 & 5.22614 & 5.02231 & 5.51105 & 5.51871 & 5.66257 & 5.53136 & 5.45783 \\
\hline piki(x2) & 5.37631 & 5.39972 & 5.49857 & 5.20763 & 4.84594 & 5.77448 & 5.50751 & 5.82575 & 5.50291 & 5.16055 & 5.26157 & 5.35203 \\
\hline pika(x3) & 5.31401 & 4.92797 & 5.6845 & 5.18964 & 5.36443 & 5.57264 & 5.2666 & 5.66142 & 5.51055 & 4.81227 & 4.39744 & 5.04446 \\
\hline maki(x4) & 4.53716 & 4.62276 & 5.15897 & 4.82984 & 5.34335 & 5.08503 & 5.02729 & 4.8951 & 4.85515 & 5.1607 & 4.38496 & 3.80343 \\
\hline maka(x5) & 4.32895 & 5.07485 & 5.34301 & 5.00247 & 5.18916 & 4.59651 & 4.71443 & 4.23611 & 4.63013 & 4.74574 & 4.94652 & 4.84564 \\
\hline
\end{tabular}

\section{KESIMPULAN}

Beberapa hal yang dapat disimpulkan dari hasil penelitian ini adalah sebagai berikut:

a) Entropi sebagai ukuran keacakan statistik suatu citra dapat digunakan sebagai descriptor tekstur keriput pada wajah manusia.

b) Lima lokasi target keriput pada wajah yaitu dahi, kedua sudut mata dan kedua daerah bawah mata adalah descriptor yang dapat digunakan sebagai fitur atau ciri penentu keriput.

c) Dengan aplikasi ini mempermudah penemuan ciri keriput yang dapat implementasikan pada sistem lain misalnya sistem klasifikasi umur manusia.

\section{DAFTAR PUSTAKA}

ACHMAD, B. \& KARTIKA, F. , 2005, Teknik Pengolahan Citra Digital Menggunakan Delphi, Andi Publishing, Yogyakarta.

BASUKI, AHMAD et al , 2007, Pengolahan Citra Digital menggunakan Visual Basic, Graha Ilmu, Yogyakarta.

AHMAD, U., 2005, Pengolahan Citra Digital, Graha Ilmu, Yogyakarta.

DRAPER, BRUCE A. et al, 2003, Recognizing face with PCA and ICA.

HSU, CHIH WEI et al, 2008, A Practical Guide to Support Vector Machine Classification, Department of Computer Science, National Taiwan University, Taipei 106, Taiwan.

\section{DEPKOMINFO,}

http://www.depkominfo.go.id/profil/visi-danmisi/ 
PETTERSON, E. et al, 2002, Automatic Representation Of Adult Aging in Facial Images.

GONZALEZ, R.C. \& WOODS, R.E., 2008, Digital Image Processing, Pearson Education, Inc.

LIAN, HUI-CHENG \& LU, BAO-LIANG, 2009, Age Estimation Using a Min-Max Modular Support Vector Machine, http://bcmi.sjtu.edu.cn/ lianhuicheng/papers/ Age\%20recognition-rev-lu-050430.pdf.

IVANCIUC, O., 2007, Applications of Support Vector Machine in Chemistry, Reviews in Computational Chemistry, Volume 23, Weinheim.

JAIN, A.K., 1995, Fundamentals of Digital Image Processing, Prentice-Hall of India, New Delhi.

GANDHI, MAULIN R., 2004, A Method for Automatic Syntesis of Aged Human Facial Images, McGill University, Canada.

MUNIR, RENALDI, 2004, Pengolahan Citra Digital dengan pendekatan Algoritmik, Penerbit Informatika, Bandung.

PUTRA, E. DARMA. 2008. Sistem Biometrika, Penerbit Andi, Yogyakarta.

RICHA, SINGH et al, 2007. Age Transformation for Improving Face Recognition Performance.

SANTOSA, B. 2007. Data Mining, Teknik pemanfaatan data untuk keperluan Bisnis, Teori dan aplikasinya, Graha Ilmu, Yogyakarta.

SOLIHAH, B \& RAHMAT, W.M. , 2007. Klasifikasi Bentuk Wajah dalam Representasi Fourier Descriptor Menggunakan Support Vetor Machine Multi Kelas, Prosiding SemanTik 07, Bandar Lampung.

VOJTECH, F. \& VACLAV, H. , 2004. Statistical Pattern Recognition Toolbox for Matlab (STPRtool) User's Guide, Czech Technical University, ftp:// cmp.felk.cvut.cz/pub/cmp/articles/FranchTR-2004-08.pdf

HORNG, WEN-BING et al, 2001. Classification of Age Groups Based on Facial Feature.

XIN GENG et al, 2007. Automatic Age Estimation Based on Facial Aging Pattern.

KWON,YOUNG H. \& NIELS DA VICTORIA LOBO, 1999. Age Classification from Facial Image. 